\title{
Alternative educational methods for teaching traditional art and architecture to Romanian children raised abroad
}

\author{
Cristina Maria Povian ${ }^{1, *}$ \\ ${ }^{1}$ Center for Research and Sustainable Development, Faculty of Architecture and Urbanism, \\ Politehnica University of Timişoara, Traian Lalescu Street, No. 2, 300223, Timișoara, Romania
}

\begin{abstract}
This paper presents alternative methods used for helping Romanian children who live abroad to discover and to keep their interest in their original country culture. The aim of this article is to analyze the existing situation of this category of children in Europe and in Italy and the existing programs which are already implemented and the outcomes in 2018. This article focuses on presenting also an architectural workshop as an alternative method of teaching and learning, realized in April 2018, in Padova, Italy with Romanian children who were born or are living in Veneto region since they were very small. The analysis of the experiment reveals that alternative methods of teaching Romanian culture, art and architecture makes the process of learning interesting and easy to be approached by children of any age and they feel more attracted to participate in this kind of activities.
\end{abstract}

\section{Introduction}

Children play, explore, and in this way they learn new things, always needing the most creative experiences to form their spontaneity and to stimulate their personality and intelligence.

Starting from the fact that the way children are raised will influence our future, and investing in their education and formation it is important to be made from an early age to be efficient, in the last years, a special attention has been given to them and their problems. The European Union through various programs and laws, many specialists from different fields through researches, studies and reports tried to assure them a proper environment and optimal conditions in order to develop themselves regardless of the context they come from or the special needs they have.

Trying to answer the questions: "How much does the architecture and interior design influence a child's development?", "If a child designs his or her own spaces (rest, play or study), how different would those be, comparing them, to those designed by an architect?" numerous studies have been conducted. A sensitivity to the built space results from most studies with children. Georges Keamin said: "It is certain that all cases of attraction to children by new pedagogical experiences have only confirmed the influence of architectural

*Corresponding author: cristina.povian@yahoo.com; cristina.povian@upt.ro 
forms on the spirit and imagination of the child." This becomes even more important if we use the architecture and design space created for them as educational, reintegration and rehabilitation methods for children with different problems, or as in this particular situation: a way to create, for children raised abroad, their national identity. [1][2]

The Romanians started to leave Romania before 1989, the phenomenon widening after the 1990s, and in the last 10 years (when Romania joined the European Union and received the right to work) a massive migration took place in Europe. In March 2013, 58.902 families went to work abroad in Romania, leaving 82.073 children without at least one parent and 23.312 children without both parents. [3]

On 30.09.2017, according to the information from the National Authority for the Protection of Children's Rights and Adoption, there were 93,648 children with at least one parent who went to work abroad, of which 29,468 had both parents or the only parent he has who had gone to work abroad. [4]

As we can see from these statistical data, this phenomenon continues to develop, requiring new social, economic, political and architectural measures to provide them with an optimal environment for their development, as well as seeking new strategies and services to prevent child separation from family. Over time, many families have been able to take their children with them in the countries where they work, leading to the need of new strategies for their integration and adaptation in the community of the country where they live, but also for maintaining a link with the country, the culture in which they were born and where they spent their first years of life.

At this category of children we have to add those children who were born abroad. The number of persons born abroad in other EU Member States or non-European Union countries who are usually resident in the reporting country was 508.625 in 2018 , increasing from 421.801 in 2017, 347.344 in 2016, 281.048 in 2015, approximately 211.210 in 2014 and 182.939 in 2013, according to EUROSTAT 209 statistics. (Fig.1.) [5]

\begin{tabular}{|c|c|c|c|c|c|c|c|c|c|c|}
\hline$\frac{\text { geo }}{\text { Larvia }}$ & $\begin{array}{c}2009 \\
-324,811\end{array}$ & $\begin{array}{c}2010 \\
-313,80\end{array}$ & $\begin{array}{c}2011 \\
32,899\end{array}$ & $\begin{array}{l}2012 \\
299,018\end{array}$ & $\begin{array}{r}2013 \\
219,221 \\
\end{array}$ & $\begin{array}{l}2014 \\
z 7,120\end{array}$ & $\begin{array}{l}2015 \\
-205,718\end{array}$ & \begin{tabular}{|r|}
2016 \\
238,8989
\end{tabular} & 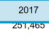 & 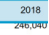 \\
\hline Lithuania & 171,179 & 160,772 & 149,544 & 143,675 & 140,221 & 137,417 & 136,021 & 129,706 & 127,351 & 130,975 \\
\hline Luxembourg & 159,030 & ${ }_{163,142}$ & 166,319 & 216,156 & 227,461 & 237,848 & 248,888 & 260,573 & $270,010^{b}$ & 200, 151 \\
\hline Hungary & 424,031 & 436,616 & 443,295 & 401,769 & 422,317 & 447,029 & 475.508 & 503,787 & 513,649 & 536,182 \\
\hline Malta & 90,474 & 33,008 & 33,591 & 35,121 & 38,815 & 44,149 & 52,642 & 61,632 & 69,576 & 83,996 \\
\hline Netherlands & $1,793,744$ & 1,832,510 & $1,868,655$ & $1,906,295$ & $1,927,728$ & $1,953,436$ & 1,996,318 & $2,056.520$ & $2,137,234$ & $2,215,84$ \\
\hline Austria & $1,259.626$ & $1,274,901$ & $1,294,224$ & $1,322.656$ & $1,384.003$ & $1,414,215$ & $1,483,233$ & $1,588.209$ & $1,649,008$ & 1.,690,61 \\
\hline Poland & 453.248 & 642,417 & $637,405 \mathrm{PP}$ & $630.478 \mathrm{P}$ & 625.363 & $620.308 \mathrm{P}$ & 611.8ssp & 626.3968 & 6551.8450 & $695.85 \mathrm{com}$ \\
\hline Portugal & 855,328 & 762,225 & 755,484 & 851,496 & 831,440 & 959,065 & 864,814 & 872,501 & 976.300 & 900,553 \\
\hline Romania & s & & & & 182,999 & $211,210^{\circ}$ & 281,048 & 347,344 & ${ }^{421,801}$ & 500,625 \\
\hline Slovenia & $243,404 \mathrm{~b}$ & 255,786 & 228.583 & 230,109 & 232,703 & 235.310 & 237,616 & 241.203 & 245.369 & 250.226 \\
\hline Slovakia & b & 64,422 & 68,135 & 156,863 & 158,164 & 174,908 & 177,624 & 181.642 & 1862217 & 190,308 \\
\hline
\end{tabular}

Fig. 1.The evolution of foreign born population from 2009 to 2018.Source: EUROSTAT[5]

The first place in the number of Romanian children born between 2007 and 2018 is Italy with 144.983 children, followed by Spain with 81.858 children, the United Kingdom with 39.903 children, Germany with 31.026, France with 24.976, Belgium with 10.399 and Austria with 8.934 children. These are only 7 of the developed European countries with most Romanian children born outside the borders in the last years. In 2017, the number of birth certificates issued for children born from at least one Romanian citizen, in the Diaspora, according to the situation registered by the Directorate for the Evidence of Persons and Administration of Databases, was 36 960. [6] This number represents $1 / 6$ of the total number of Romanian children born this year, 189,474. [7]

These statistical data show that as a result of the migration made over the last 20 years, Romanian communities must have been created on the territory of these countries. As a necessity, an international project developed within a partnership between the Ministry of Education of Romania and other European Union member states of teaching and 
promoting the Romanian culture and language "Romanian Language, Culture and Civilization Course (LCCR)". [8]

The course started in 2007, first only in two countries: Italy and Spain, started in 2008 also in Belgium, then in 2015-2016 to expand in Ireland and Portugal and in 2017-2018 in the UK. The project has benefited from a real success, the main progress indicator being the number of schools that have expressed their willingness to have the school offer and the increase of the participating schools with each passing year. If in 2007 a number of 1500 pupils were enrolled in the school year 2016-2017, the course was taught in over 500 schools in Italy, Belgium, Ireland, Portugal and Spain by 134 teachers and about 13,000 students benefited about it. Compared to the previous year, the participation percentage was $23.40 \%$ higher. [9][10]

The aim of this course was to assure the Romanian children living abroad the necessary conditions for the preservation of their cultural identity as well as minimal knowledge that will facilitate their reintegration into the Romanian educational system in the event of their return to the country.

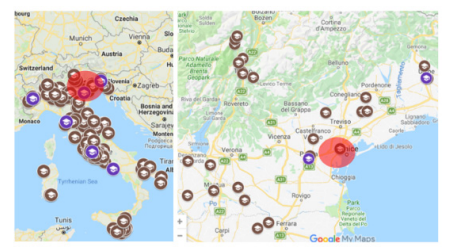

Fig. 2. The maps of "Romanian Language, Culture and Civilization Course (LCCR)" in Italy and in Veneto Region [8]

\section{Methodology}

\subsection{Premises and assumptions}

The structure of the Romanian school community from the countries belonging to the European Union is diverse and can be made up of: children born and who have studied for a while in Romania, children born abroad and having minimal contact with the country of their parents and with Romanian language and culture. Both categories of children face problems of adaptation, integration, recognition and assuming a cultural and linguistic identity.

\subsection{Subjects and methods}

The case study which is presented in this research was realized in April 2019, in Padova, Veneto Region of Italy. In 01.01.2018, Veneto region is ranked 4th as Romanian citizens residing in Italy with 122.751 people, after the regions Lazio, Lombardia and Piemonte. In this region there are 7 units of pre-university education and one university where these courses of "Romanian Language, Culture and Civilization" are held. [11] (Fig.2.)

At the presentation participated 38 persons from which 22 children, with the age between 4 to 12 years old, who participated to all the activities, from "Quinto I.C. di Padova" Donatello", Padova, Italy. They were accompanied by parents and were coordinated by their "Romanian Language, Culture and Civilization Course (LCCR)" teacher, Ioana Opriș. The creative workshop "Little Architects- architecture and Romanian traditional motifs and ornaments" was realized by the Faculty of Architecture and 
Urbanism, Politehnica Timişoara with the support of the „Romanian Institute of Culture and Humanistic Research in Venice".

\subsection{Case study on the Workshop "The Little Architects- architecture and Romanian traditional motifs and ornaments"}

Taking into account the new active learning approaches, the aim of this article is to present the result of the architectural workshop „Little Architects” held at Padova. The workshop activities focused on how this alternative education activities can help in order to attract more children to discover the Romanian Culture and Art, and not only Romanian children but also Italian ones.

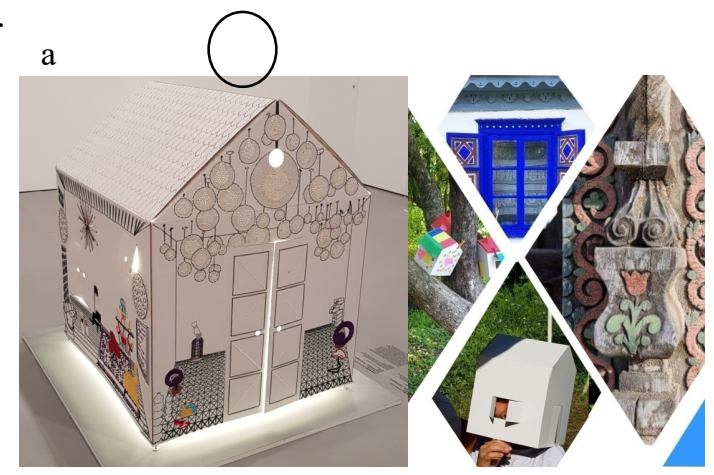

$\mathrm{b}$

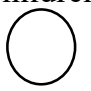

Fig. 3. a) "Casa all'italiana" by Anila Rubiku; b) The prototype created and some inspirational sources for the workshop [13]

The practical part of the workshop used a prototype inspired by an art piece of Anila Rubiku born in Albania, "Casa all'italiana", a small house akin to the naive schemes in children's drawings. (Fig.3.a.) The same prototype was used in the summer of 2018 to another workshop held in Romania in 5 villages from Timiş County. During the summer school „The Non-formal Comes to the Village", "Alternativ Education” association in partnership with Faculty of Architecture and Urbanism from "Politehnica" Timișoara helped children from the rural area to decorate almost 200 small cardboard houses in the theme "My ideal home". [12]

The workshop was structured in two parts: a presentation and a practical activity.

In the first part at the beginning the children had to draw on a paper three thinks that represents for them Romania. After that they watched presentations about Romanian decorative symbols in: architecture, interior design, household items like carpets, ceramics the traditional Romanian garment and jewellery. They have learned about the famous wood churches, their amazing handmade decorations and their symbolic importance. Movies with virtual tours of the most important museums of the Romanian traditional villages were projected in order to create an idea about how was the life in a village and the mechanism of a family living in that type of houses and villages. They have learned about the most important traditional pieces of furniture like the traditional three legs stool which was used as a source of inspiration in the design of modern furniture (Romanian pavilion at 2008 Biennale of Architecture in Venice), the stove, etc.

In the second part they had the practical work: to decorate the small cardboard models representing a simple house, with Romanian symbols and decorations that they have seen and memorized during the presentations in order to create a traditional Romanian village. (Fig.3.b.) During the practical part, the movies with the virtual tours of the museum have been projected in the background, in order to inspire them in the process of creation. 
Even if each child decorated his own house in an original way, in the end it was a team work, they had to establish some connections between the houses in order to create their own traditional Romanian village in Italy. (Fig.4.)

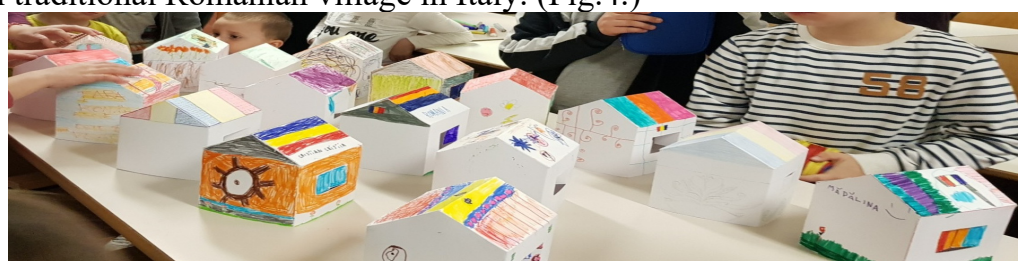

Fig. 4. The final result from the activity concretized through a traditional Romanian cardboard village [13]

\section{Results and discussions}

At the activity participated children with the age between 4 to 12 years old witch made the workshop more challenging and the results diversified. If at the question "What Romania means to them?" the responses were diversified: relatives, grandma, friends animals, the cat, the poet Mihai Eminescu, the Palace of Parliament, holidays, different types of food, nature, smile faces, the Romanian flag or Dracula's castle, etc.; we could notice that $90 \%$ them are influenced by feelings. (Fig.5.) Analyzing the responses we can see that we can divide them in two main categories: the one related with the experience they had there and feelings (holidays, relatives, animals) and the other one related to what they have heard or learned from their parents or at the courses of "Romanian Language, Culture and Civilization" which are held in their school.
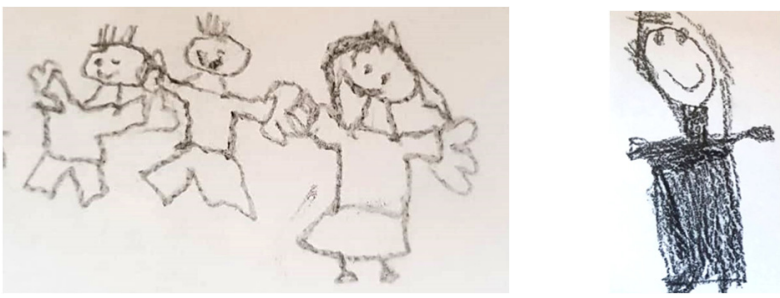

Fig. 5. The drawings representing the responses to the question: "What Romania represents to you?" (a. Family; b. grandma) [13]
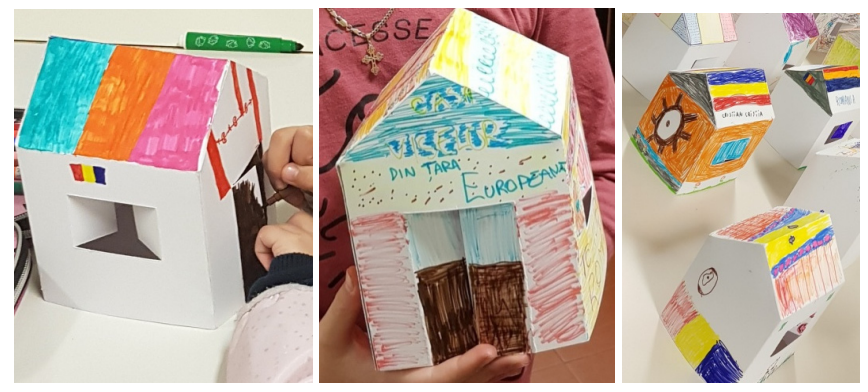

Fig. 6. The flag used in the decoration of cardboard houses. [13] 


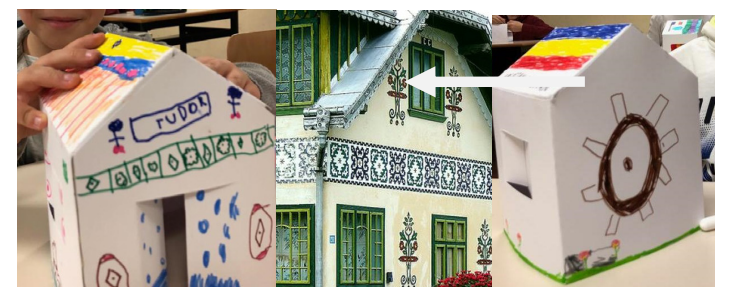

Fig. 7. One of the images presented as a source of inspiration during the workshop and the result in the work of children. [13]

The most important conclusion, resulted from the fact that $92 \%$ of children have drawn the Romanian flag, is that for them the colours are very important to define something. Also in a foreign country the Romanian flag it is an element of recognition of the Romanian institutions with which they take contact: embassy, consulate, church, etc. Even if after the presentation, they decorated the cardboard houses with elements from the presentations or the images they seen (Fig. 7.), we could notice that the flag or the colours from the Romanian flag (red, yellow and blue) were still mainly used in decorating the entire roof or just like a small symbol on the facade of the house. (Fig. 6., 7.) The use of it as a decorative symbol is one of the major differences noticed between the way the children from Romanian villages decorated their houses in 2018 (using a lot of green and sometimes even leaves or natural elements) and the Romanian children from Veneto region decorated their own cardboard houses (with the colours of the Romanian flag).

The main objectives and results of the workshop were:

- Acquiring new knowledge related to Romanian traditional architecture and art.

-Watching animation movies and documentaries meant to arouse their curiosity in Romanian culture;

- Increasing the interest for Romanian culture and developing a relationship with the country from which they come from, among through educational activities that combine games and passing on new concepts. In this way they can feel more attracted to go to the "Romanian Language, Culture and Civilization".

- Developing the capacity of principle relationship and communication with other children with the same cultural background as them, in order to help them to adapt and integrate in a foreign country.

- Acquiring communication and socialization skills through creative work and team work, when they had to create their own traditional Romanian village.

\section{Conclusions}

The analysis of the workshop results indicates that the active teaching and learning method is efficient for children very young and attract them in an interactive way to discover their original country's art and architecture, in order to define their own spatial identity after that, even if they decide to live the rest of their life in other countries or even if they come back in Romania.

Research realized during the internship at „Instituto Romeno di Cultura e Ricerca Umanistica di Venezia", obtained with the support of the Romanian state through the national scholarship program „Nicolae Iorga". 


\section{References}

1. J. Piaget, B. Inhelder, Psihologia copilului, Editura Cartier Polivalent, (2005)

2. C.M. Povian, C. Dumitrescu, Architectural guidelines for building a special learning environment for children in need, Procedia Social and Behavioral Sciences, Volume 186, pp. 131-136, (2015)

3. Ministry of Labor, Family, Social Protection and the Elderly - National Authority for the Protection of Child's Rights and Adoption, Statistics, Online source: http://www.copii.ro/alte_categorii.html Consulted on July 2014.

4. National Authority for the Protection of Child's Rights and Adoption, Activity Reports, Online source: http://www.copii.ro/anpdca-content/uploads/2017/08/MO-341-Raportde-activitate-ANPDCA.pdf Consulted on October 2018.

5. EUROSTAT, Foreign born population, (2019) Online source: https://ec.europa.eu/eurostat/tgm/table.do?tab=table\&init=1\&language $=$ en \&pcode $=$ tps 00178\&plugin=1 Consulted in June 2019.

6. Ministry of Internal Affairs, Government of Romania, Ministry of Relations with Parliament, Statistics and reports, (2018), Consulted in June 2019. Online source: http://www.cdep.ro/interpel/2018/r5306A.pdf

7. National Institute of Statistics INS, Demographic events in 2017, (2018) Source: http://www.insse.ro/cms/sites/default/files/field/publicatii/evenimente_demografice_in _anul_2017.pdf Consulted in June 2019.

8. Romanian Embassy in the Italian Republic, Romanian Language, Culture and Civilization Courses (LCCR), Source: https://roma.mae.ro/node/949 Consulted in 22.04.2019

9. Ministry of national education, 2017- Online source : https://www.edu.ro/cursul-delimb $\% \mathrm{C} 4 \% 83$-cultur\%C4\%83-\%C8\%99i-civiliza $\%$ C8\%9Bie-

rom $\% \mathrm{C} 3 \% \mathrm{~A} 2$ neasc $\% \mathrm{C} 4 \% 83$-va-fi-predat-\%C8\%99i-\%C3\%AEn-\%C8\%99coli-dinmarea-britanie Consulted in May 2019.

10. The Romanian language institute, (2019), Source : https://www.ilr.ro/lccr/ Consulted in May 2019

11. Romanian Embassy in the Italian Republic, The Romanian community, Consulted in 22.04.2019, Source: https://roma.mae.ro/node/290

12. C.M. Povian, "The Little Architects" Workshop an active learning and teaching method for children in need, (to be published)

13. Personal photos, (2019) 